\title{
A case of isolated TSH deficiency presenting as infertility
}

\author{
Adam H. Balen and Patrick J. Manning \\ Department of Endocrinology, Cobbold Laboratories, The Middlesex Hospital, Mortimer Street, London \\ WIN 8AA, UK
}

\begin{abstract}
Summary: We report a case of late-onset isolated thyroid stimulating hormone deficiency in a woman who presented with oligomenorrhoea and secondary hyperprolactinaemia. Hypothalamic and pituitary radiology and function was otherwise normal. The underlying aetiology of this condition is thought to be due to an inborn defect in the thyrotroph and treatment is with standard thyroid replacement therapy.
\end{abstract}

\section{Introduction}

Isolated deficiency of thyroid stimulating hormone (TSH) is rare. We report the case of a 35 year old woman who presented with infertility, oligomenorrhoea and hyperprolactinaemia. She was found to be hypothyroid and, after extensive investigations, this was found to be due to isolated TSH deficiency.

\section{Case history}

The patient, a government officer, first presented to her local gynaecologist in 1985, at the age of 30 years. She was complaining of primary infertility. After her menarche, at the age of 14 years, she had had an irregular menstrual cycle and was prescribed the combined oral contraceptive pill until she married in 1982. Her cycle was again erratic and she was found to have a serum prolactin concentration of $1,100 \mathrm{mU} / \mathrm{ml}$. An X-ray of her pituitary fossa was normal and so she was prescribed clomiphene citrate but failed to respond. Bromocriptine was then prescribed but, because of side effects, she was then referred for further evaluation and, in the meantime, given the oral contraceptive pill to regulate her cycle.

On examination the patient had mild facial hirsutism and no acne. She was normotensive and of normal weight (body mass index $22.45 \mathrm{~kg} / \mathrm{m}^{2}$ ). She had no galactorrhoea and her visual fields were normal.

An initial endocrine profile was mistakenly performed whilst the patient was still taking the contraceptive pill, the gonadotrophins were consequently suppressed and the total serum thyroxine $\left(\mathrm{T}_{4}\right)$ concentration was $87 \mathrm{nmol} / \mathrm{l}$ (normal range $60-160 \mathrm{nmol} / \mathrm{l}) ;$ a measurement of thyroid

Correspondence: A.H. Balen, M.R.C.O.G.

Accepted: 18 August 1993 stimulating hormone (TSH) was requested but, unfortunately, not performed. After stopping the contraceptive pill for 3 weeks, the patient's follicular phase serum hormone concentrations were: serum prolactin concentration $1,340 \mathrm{mU} / 1$ (normal range $0-360 \mathrm{mU} / 1$ ), follicle stimulating hormone (FSH) $3.9 \mathrm{IU} / 1$ (normal < $6 \mathrm{IU} / \mathrm{l})$, luteinizing hormone (LH) $5.0 \mathrm{IU} / 1$ (normal < $10 \mathrm{IU} / \mathrm{l})$, oestradiol $668 \mathrm{pmol} / 1$ (normal $40-1,300 \mathrm{pmol} / \mathrm{l}$ ), testosterone 1.0 (normal $0.5-2.5) \mathrm{nmol} / 1$ and androstenedione $1.4 \mathrm{nmol} / 1$ (normal $2-10 \mathrm{nmol} / \mathrm{l}$ ). Pelvic ultrasound demonstrated normal ovaries and a computed tomographic (CT) scan of the pituitary fossa was normal. Bone mineral densitometry was also normal.

The patient was having marital difficulties and so decided to restart the contraceptive pill. When she was reviewed 3 months later she complained of a number of non-specific symptoms. A repeat endocrine profile revealed a low total thyroxine concentration of $32 \mathrm{nmol} / 1$ (normal $60-160 \mathrm{nmol} / \mathrm{l}$ ) and the TSH was below the limit of detection of the assay $(<0.2 \mathrm{mU} / 1$, normal range of $0.5-5.0 \mathrm{mU} / \mathrm{l})$. The free $\mathrm{T}_{4}$ was $3.66 \mathrm{pmol} / \mathrm{l}(9.0-22.0 \mathrm{pmol} / \mathrm{l})$, free tri-iodothyronine $\left(\mathrm{T}_{3}\right) 7.27 \mathrm{pmol} / \mathrm{l}(4.3-8.6 \mathrm{pmol} / \mathrm{l})$ and the thyroxine-binding globulin $13.1 \mathrm{mg} / 1$ $(7.0-17.0 \mathrm{mg} / \mathrm{l})$. The patient's serum and urine biochemistry, and endocrine profiles were otherwise normal, and there were no symptoms of pituitary insufficiency. The patient was, however, noted to have lost $5 \mathrm{~kg}$ in weight in the 6 months since her first visit.

The patient was further investigated with a magnetic resonance imaging (MRI) scan of her hypothalamus and pituitary, which was normal. An insulin tolerance test and an anterior pituitary function test were performed. The following were administered intravenously: 0.1 units of insulin $/ \mathrm{kg}$, $200 \mu \mathrm{g}$ thyrotrophin releasing hormone (TRH) and $100 \mu \mathrm{g}$ gonadotrophin-releasing hormone ( $\mathrm{GnRH})$. 
Adequate hypoglycaemia was achieved and there was an adequate response of the adrenocortical, growth hormone and gonadotrophin axes, but no response of TSH to exogenous TRH and a suppressed response of prolactin to TRH. The TRHstimulation test was repeated one month later and similar results were obtained. A diagnosis was made of isolated TSH deficiency. The TSH levels were under $0.2 \mathrm{mU} / 1$ from 0 to 12 minutes.

The patient was commenced on thyroxine replacement therapy and now, 18 months later, is feeling well and is clinically and biochemically euthyroid. Her serum prolactin concentration has also returned to the normal range. Unfortunately, her marriage has broken up and fertility is no longer an issue. She has a new partner and continues to take the combined oral contraceptive. We therefore do not know if her natural cycle is now regular.

\section{Discussion}

The mature thyroid follicular cell can modify iodine transport or uptake relative to dietary iodine intake, exclusive of variations in serum TSH, ${ }^{1}$ and this mechanism has developed in the human by about 36 weeks gestation. ${ }^{2}$ It is impossible to know the natural history of the TSH deficiency that has been described in this case. There certainly appears to have been autonomous thyroid function up to the time of diagnosis, with serum free $T_{3}$ concentrations just below the normal range, indicating fully compensated TSH deficiency. Isolated TSH deficiency is very rare, ${ }^{3}$ although the exact incidence is unknown. Congenital isolated TSH deficiency is an autosomal recessive disease that manifests itself as neonatal hypothyroidism (cretinism) with its associated mental and growth retardations. ${ }^{4,5}$ Some groups have found genetic abnormalities to account for the syndrome. , $^{6}$ which appears to involve a problem with formation of the TSH beta-subunit. ${ }^{8}$

Isolated TSH deficiency was first reported by Shuman ${ }^{9}$ and since then only sporadic cases have been reported. Indeed the isolated deficiency of any pituitary hormone is uncommon and usually secondary to an acquired and often progressive problem. Odell ${ }^{10}$ reported a series of 10 cases of isolated TSH deficiency, whose ages ranged from 27 to 60 years. In the majority of these cases the hypothyroidism was mild and suspected clinically only with difficulty. Burke et al. ${ }^{11}$ reported the case of isolated TSH deficiency in a 55 year old man to whom TRH was administered for 23 days with no resultant elevation of TSH. Whilst TSH secretion has been shown after prolonged administration of TRH, suggesting that the defect may be partial in some patients, the underlying defect in such cases might have been TRH deficiency as reported by Katakami et al. ${ }^{12}$

The mildly elevated serum concentration of prolactin in our patient may be a reflection of TRH stimulation of the lactotroph and confirms that the problem lay at the pituitary rather than hypothalamic level. The normalization of the serum prolactin concentration with thyroxine therapy further suggests that the problem was pituitary TSH deficiency rather than hypothalamic TRH deficiency. The stimulation of prolactin secretion by TRH has previously been reported in a case of isolated $\mathrm{TSH}$ deficiency ${ }^{13}$ and suggests that the TRH receptors are intact in this condition. Furthermore, patients with primary idiopathic hypothalamic hypothyroidism demonstrate normal pituitary responsiveness to TRH. ${ }^{14}$

The cause of the patient's oligomenorrhoea and infertility could have been secondary to either hypothyroidism or hyperprolactinaemia. The precise mechanism through which hypothyroidism causes infertility is uncertain and might be through a perturbation of prolactin secretion ${ }^{15}$ but correction of the thyroid status often restores a normal menstrual cycle.

\section{Acknowledgement}

We are grateful to Professor H.S. Jacobs for allowing us to report this case.

\section{References}

1. Penel, C., Rognoni, J.B. \& Bastiani, P. Thyroid autoregulation: impact on thyroid structure and function in rats. $A m J$ Physiol 1987, 16: E165-E172.

2. Castaing, H., Fournet, J.P., Leger, F.A. et al. Thyroid of the newborn and postnatal iodine overload. Arch Franc Pediat 1979, 36: 356-358.

3. Fisher, D.A. \& Polk, D.H. Development of the thyroid. In: Jones, C.T. (ed.) Perinatal Endocrinology. Bailliere's Clinical Endocrinology \& Metabolism, Vol. 3, 1989, pp. 627-658.

4. Miyai, K., Azukizawa, M. \& Kumahara, Y. Familial isolated thyrotrophin deficiency with cretinism. N Engl J Med 1971, 285: $1043-1048$.

5. Labbe, A., Dubray, C., Gaillard, G., Besse, G., Assali, P. \& Malpuech, G. Familial growth retardation with isolated thyroid-stimulating hormone deficiency. Clin Pediat 1984, 23: 675-678.

6. Hayashizaki, Y., Hiraoka, Y., Endo, Y., Miyai, K. \& Matsubara, K. Thyroid stimulating hormone deficiency caused by a single base substitution in the CAGYC region of the beta-subunit. EMBO J 1989, 8: 2291-2296.

7. Mori, R., Sawai, T., Kinoshita, E. et al. Rapid detection of a point mutation in thyroid-stimulating hormone beta-subunit gene causing congenital isolated thyroid-stimulating hormone deficiency. Jinrui Idengaku Zasshi 1991, 36: 313-316. 
8. Miyai, K., Endo, Y., Iijima, Y., Kabutomori, O. \& Hayashizaki, Y. Serum free thyrotrophin subunit in congenital isolated thyrotrophin deficiency. Endocrinol Jap 1988, 35: $517-521$.

9. Shuman, C.R. Hypothyroidism due to thyrotropin deficiency without other manifestations of hypopituitarism. J Clin Endocrino Metab 1953, 13: 795-800.

10. Odell, W.D. Isolated deficiencies of anterior pituitary hormones. JAMA 1966, 197: 176-186.

11. Burke, C.W., Moore, R.A., Rees, L.H., Bottazo, G.F., Mashiter, K. \& Bitensky, L. Isolated ACTH deficiency and TSH deficiency in the adult. $J R$ Soc Med 1979, 72: 328-335.

12. Katakami, H., Kato, Y., Inada, M. \& Imura, H. Hypothalamic hypothyroidism due to isolated thyrotropinreleasing hormone (TRH) deficiency. $J$ Endocrinol Invest 1984, 7: 231-233.
13. Sachson, R., Rosen, S.W., Cuatrecasas, P., Roth, J. \& Frantz, A.G. Prolactin stimulation by thyrotropin-releasing hormone in a patient with isolated thyrotrophin deficiency. $N$ Engl $J$ Med 1972, 287: 972-975.

14. Gharin, H. \& Abboud, C.F. Primary idiopathic hypothalamic hypothyroidism. Am J Med 1987, 83: 171-174.

15. Blackwell, R.E., Chang, R.J. \& Cragun, J.R. Prolactin disorders in infertility. In: Seibel, M.M. (ed.) Infertility - A Comprehensive Text. Appleton \& Lange, Connecticut, 1990, pp. $97-110$. 